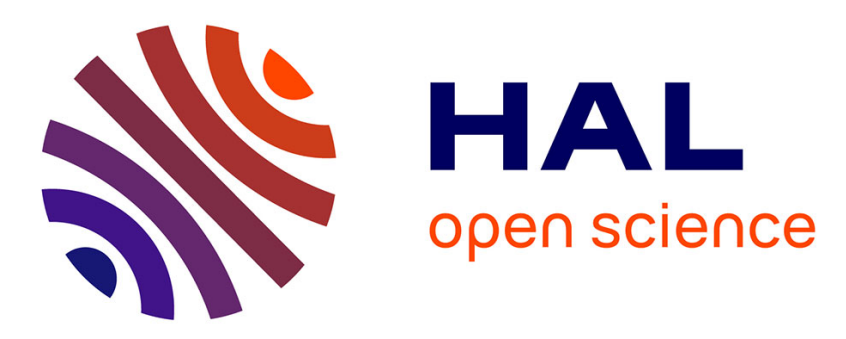

\title{
Nacre, a natural, multi-use, and timely biomaterial for bone graft substitution
}

\author{
Ganggang Zhang, Alice Brion, Anne-Sophie Willemin, Marie-Hélène Piet, \\ Vanessa Moby, Arnaud Bianchi, Didier Mainard, Laurent Galois, Pierre \\ Gillet, Marthe Rousseau
}

\section{To cite this version:}

Ganggang Zhang, Alice Brion, Anne-Sophie Willemin, Marie-Hélène Piet, Vanessa Moby, et al.. Nacre, a natural, multi-use, and timely biomaterial for bone graft substitution. Journal of Biomedical Materials Research Part A, 2017, 105 (2), pp.662-671. 10.1002/jbm.a.35939 . hal-02112022

\section{HAL Id: hal-02112022 \\ https://hal.science/hal-02112022}

Submitted on 26 Apr 2019

HAL is a multi-disciplinary open access archive for the deposit and dissemination of scientific research documents, whether they are published or not. The documents may come from teaching and research institutions in France or abroad, or from public or private research centers.
L'archive ouverte pluridisciplinaire HAL, est destinée au dépôt et à la diffusion de documents scientifiques de niveau recherche, publiés ou non, émanant des établissements d'enseignement et de recherche français ou étrangers, des laboratoires publics ou privés. 


\title{
Review Article
}

\section{Nacre, a natural, multi-use, and timely biomaterial for bone graft substitution}

\author{
Ganggang Zhang, Alice Brion, Anne-Sophie Willemin, Marie-Hélène Piet, Vanessa Moby, \\ Arnaud Bianchi, Didier Mainard, Laurent Galois, Pierre Gillet, Marthe Rousseau
}

Faculté de médicine, IMoPA, UMR 7365 CNRS Université de Lorraine, Vandoeuvre-lès-Nancy, France

Received 17 June 2016; revised 23 September 2016; accepted 13 October 2016

Published online 00 Month 2016 in Wiley Online Library (wileyonlinelibrary.com). DOI: 10.1002/jbm.a.35939

\begin{abstract}
During the past two decades, with a huge and rapidly increasing clinical need for bone regeneration and repair, bone substitutes are more and more seen as a potential solution. Major innovation efforts are being made to develop such substitutes, some having advanced even to clinical practice. It is now time to turn to natural biomaterials. Nacre, or mother-ofpearl, is an organic matrix-calcium carbonate coupled shell structure produced by molluscs. In vivo and in vitro studies have revealed that nacre is osteoinductive, osteoconductive, biocompatible, and biodegradable. With many other outstanding qualities, nacre represents a natural and multi-use
\end{abstract}

biomaterial as a bone graft substitute. This review aims at summarising the current needs in orthopaedic clinics and the challenges for the development of bone substitutes; most of all, we systematically review the physiological characteristics and biological evidence of nacre's effects centred on osteogenesis, and finally we put forward the potential use of nacre as a bone graft substitute. (c) 2016 Wiley Periodicals, Inc. J Biomed Mater Res Part A: 00A:000-000, 2016.

Key Words: nacre, bone graft substitute, biomineralization, biomaterial, clinical applications

How to cite this article: Zhang G, Brion A, Willemin A-S, Piet M-H, Moby V, Bianchi A, Mainard D, Galois L, Gillet P, Rousseau M. 2016. Nacre, a natural, multi-use, and timely biomaterial for bone graft substitution. J Biomed Mater Res Part $A$ 2016:00A:000-000.

\section{INTRODUCTION}

Nacre, or mother-of-pearl, is a calcium carbonate structure present in mollusc shells. In vivo and in vitro studies have revealed that nacre is osteoinductive, osteoconductive, biocompatible and biodegradable. Its vast and extensive availability, competitive cost, opacity to $\mathrm{X}$ rays, unique hierarchal structure, chemical complexity and outstanding mechanical properties all make nacre a natural and multi-use biomaterial as a bone graft substitute. Nevertheless, nacre has not yet drawn enough attention from investigators. This review aims at pointing out the current needs in orthopaedic clinics and the challenges for the development of bone substitutes, and principally to systematically review the physiological characteristics and biological evidence of nacre's contribution centred on osteogenesis, and thus to foresee the potential use of nacre as a bone graft substitute.

What are the real needs for a bone graft substitute in current orthopaedic clinics?

There are three main types of bone grafts: autografts, allografts, and bone graft substitutes. There are, however, some well-known drawbacks, for example, restricted supply or disease transmission. The application of autograft and allograft is greatly limited. ${ }^{1,2}$ Thus, hope has turned to bone graft substitutes. ${ }^{3}$ To date, no one bone graft substitute is able to satisfy all the clinical demands. Large bone loss due to trauma, infection and tumoral diseases at different sites should be treated differently. To meet the major requirements of a bone graft substitute, a $4 \mathrm{Fs}$ rule was introduced: form, function, fixation and formation. ${ }^{3}$ Form means that the scaffold should fill the bone defect cavities. Function is the load-bearing property. Fixation requires scaffolds to be securely attached to the bone at the defect margins, eliminating motion between host bone and scaffold to avoid nonunion and pseudarthrosis. Formation means that scaffolds should promote bone formation. For all cases, the 4Fs should be respected. While cranial surgery has more demands concerning the form, orthopaedic surgery, particularly the treatment of severe fracture or limb reconstruction, has a higher requirement for function and fixation. In the case of delayed healing fractures, non-unions and infection,

All authors approved the entirety of the submitted material and contributed actively to the study.

Correspondence to: M. Rousseau; e-mail: marthe.rousseau@univ-lorraine.fr

Contract grant sponsor: China Scholarship Council 

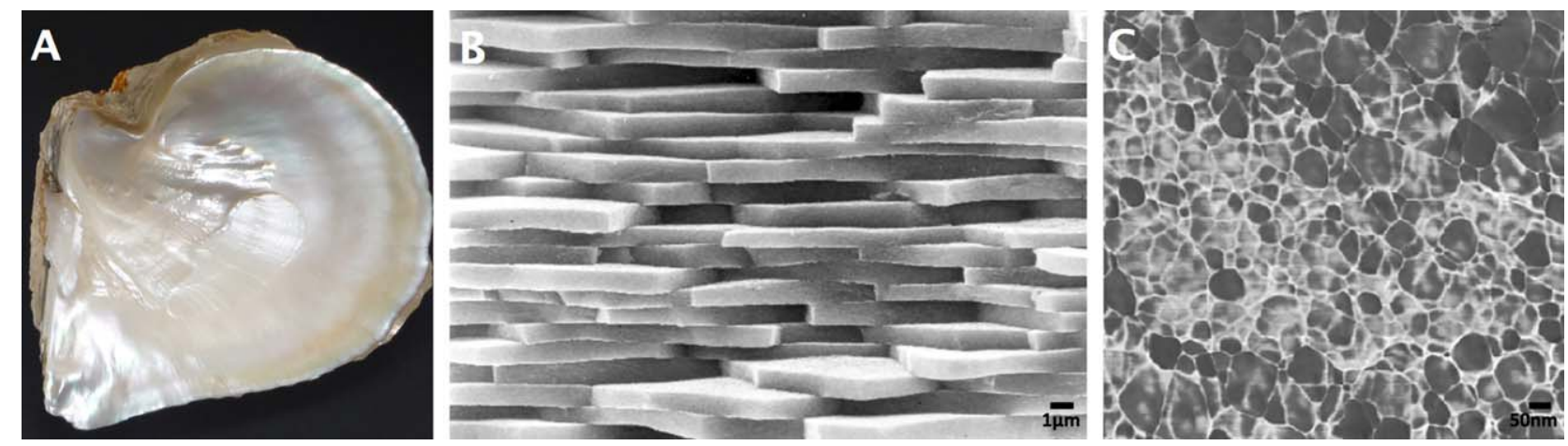

FIGURE 1. Structure of the nacreous layer of Pinctada: A: Lustrous nacreous layer as an internal shell coating; B: Scanning Electron Microscopy picture showing the characteristic brick and mortar structure of nacre; C: Atomic Force Microscopy image in Phase Contrast mode $\left(1 \times 1 \mu \mathrm{m}^{2}\right)$ at the nanometer $(\mathrm{nm})$ length scale.

orthopaedic clinics need treatment for bone formation. Furthermore, in spinal surgery, implants in the vertebral body need to be injectable, particularly when a mini-invasive approach is taken. The handling characteristics of different substitutes are very important for the orthopaedic surgeon. Similarly, the implants for maxillofacial and dental surgery have different requirements. Clinically, the choice of bone graft substitutes depends on several factors ${ }^{4}$ : (1) the intended clinical application; (2) defect size and total bone mass required; (3) biomechanical properties; (4) chemical composition; (5) availability; (6) desired bioactivity (osteoconductivity/osteoinductivity/osteogenicity); (7) desired resorption rate; (8) handling characteristics; (9) associated side effects; (10) cost; (11) ethical issues. On the whole, the bone graft substitute should meet the multiple needs of any given specific case.

\section{Current mainstream ideas on bone graft substitutes and the main dilemma}

The focus on synthetic bone graft substitutes is currently aimed at improving their osteogenic, osteoconductive and osteoinductive potential. Osteogenesis implies the formation of bone matrix by bone-forming cells. Osteoconduction means bone growth on a surface: an osteoconductive surface permits bone growth on its surface or deeper down into pores, channels or pipes. ${ }^{5}$ Osteoinduction means the recruitment of undifferentiated mesenchymal stem cells from the surrounding tissue and the stimulation of these cells to develop into preosteoblasts for bone regeneration. ${ }^{5,6}$ Osseointegration is also an important concept, that of the stable anchorage of an implant achieved by direct bone-toimplant contact. ${ }^{5}$ Although $>21,000$ papers on bone substitutes have been published in the last 20 years (PubMed search), bone substitutes have not all led to clinical practice because of several limitations or challenges, ${ }^{3,4,7-9}$ related to techniques, business, or philosophy. The most urgent or toughest-to-satisfy ones are the following: (1) to develop mechanically strong porous scaffolds that retain proper vascularization and host integration properties; (2) to assess graft functionality in load-bearing large animal models; (3) to avoid single-component strategies involving cells, factors, or defect-filling materials; (4) to modulate the host's foreign-body response; (5) to solve the contradiction between the strategies incorporating all the necessary components with the difficulty in obtaining regulatory approval; (6) to assess technical difficulties, efficiency, cost during the manufacturing process and safety risks during the preimplantation period; (7) to meet specific market needs.

\section{NACRE}

The core biological knowledge on nacre

Nacre (mother-of-pearl) is an acellular calcium carbonate composite produced worldwide by bivalves, gastropods, and cephalopods as an internal shell coating [Fig. 1(A)]. The structure and formation of nacre, particularly in giant oysters Pinctada (P.) maxima and P. magaritifera, is among the best-studied examples of calcium carbonate biomineralization, which gives a biomimetic approach for current bone substitutes.

Physical structure. P. margaritifera and $P$. maxima are among the largest Pinctada species (family Pteriidae). The largest $P$. margaritifera shells can reach $30 \mathrm{~cm}$ in diameter, versus $20-25 \mathrm{~cm}$ for $P$. maxima. The thickness of the $P$. maxima nacre layer can be up to $2 \mathrm{~cm}^{10}$ These parameters endow nacre with great potential to design bone graft substitutes. At the microscopic scale, nacre is composed of aragonite crystal tablets covered by and embedded in an organic matrix. The typical structure of Pinctada nacre involves a regular brick wall-like edifice, composed of pseudohexagonal aragonite tablets about $0.5-\mu \mathrm{m}$ in thickness -thick and 5-15 $\mu \mathrm{m}$ in diameter [Fig. 1(B)]. ${ }^{11}$ The tablets are arranged in continuous parallel laminae separated by sheets of an interlamellar organic matrix. ${ }^{12}$ On the nano-scale, the tablet itself is a composite containing both the mineral structure of aragonite and the intracrystalline organic material [Fig. 1(C)]. ${ }^{12,13}$ Because of the particular layered microstructure and organic components, nacre presents excellent compressive stress properties better than those of bone. The Young's modulus, or the elastic modulus, is $30-40 \mathrm{GPa}$ for nacre versus $20 \mathrm{GPa}$ for bone, and the respective values of resistance to failure are 185$200 \mathrm{MPa}$ versus $140 \mathrm{MPa}^{14,15}$ 
Chemical composition. The inorganic fraction (97\%) of nacre is composed of calcium carbonate in the form of aragonite. The organic fraction $(3 \%)$ is a mixture of proteins, peptides, glycoproteins, chitin, lipids, and pigments. ${ }^{16}$ To date, $>50$ proteins and 50 peptides from nacre have been identified (UniProt protein database, see www.uniprot.org). The organic molecules can be extracted with aqueous and organic solvents. ${ }^{17}$

\section{NACRE AND BONE}

The formation of bone and shell are both multi-gene regulated and environmentally-related biomineralization processes. Nacre is an acellular structure of the external skeleton of molluscs whereas bone is a cellularized structure of the internal skeleton of vertebrates. These two highly organized structures share an intervening organic matrix deposited by specialized cells: bone cells in vertebrates and epithelial mantle cells in molluscs. The organic framework provides a scaffold for crystallization and directs the mineralization. A good understanding and comparison of their physiological formation and hierarchical structure is a necessary prerequisite to promote the value of nacre as a bone graft substitute.

Biology of bone. Bone can be seen as an open cell composite material composed of osteogenic cells, an extracellular matrix, proteins, growth factors, mineral calcium phosphate in the form of hydroxyapatite and a complex vascular system. Ossification occurs via intramembraneous or endochondral pathways. In both cases, mesenchymal cellular condensation first occurs and serves as a template for subsequent ossification. The mesenchymal stem cells (MSCs) are stimulated or regulated by abundant signal molecules, ${ }^{18}$ so that they migrate to a specific site, proliferating and differentiating into osteoblasts. Osteoblast differentiation occurs in three stages: (1) cell proliferation, (2) matrix maturation, and, (3) mineralization. Both ossification processes are involved during bone remodelling to maintain a balance between osteoclastic bone resorption and osteoblastic bone formation, in order to always maintain healthy bone, and homeostasis between the calcium and phosphates.

Structure of bone. There are two main structures, the outer cortical bone and the inner cancellous trabecular bone. Cortical bone is very dense and consists of hierarchical structures. They range from the solid material $(>3 \mathrm{~mm})$, to the cylindrically organized osteons $(10-500 \mu \mathrm{m})$, lamellae (3$20 \mu \mathrm{m})$, and the collagen-mineral composite (60-600 $\mathrm{nm})$. The primary function of cortical bone is to allow torsion, and to furnish bending resistance and compressive strength. Cancellous bone consists of an interconnected network of trabeculae which is usually filled with marrow. ${ }^{19}$ The porous trabeculae are metabolically active and are remodelled more frequently than cortical bone.

Conservation of signal molecules involved in biomineralization control in vertebrate bone and mollusc shell. It is believed that there is conservation of the signal molecules involved in the biomineralization control in calcifying matrices of bone and shell. One facet of matrix-mediated control arises from the bone and nacre interaction. In vivo experiments of nacre implants have established its biocompatibility and osteogenic activity in bone (detailed in part 3.1). In vitro studies have provided evidence of the presence, in the nacre organic matrix, of signal molecules responsible for the recruitment of mammal cells in the osteogenic pathway and bone cell activation undergoing a complete sequence of mineralization (detailed in In vitro Studies section).

\section{THE SYSTEMIC BIOLOGICAL EVIDENCE OF NACRE FOR BONE GRAFT SUBSTITUTION}

The medical use of nacre in humans has a long history. As recorded in Bencao Tujing (Illustrated Classics of Materia Medica) written in 1061, traditional Chinese medicine used a decoction of nacre powder to treat hepatopathy for $>1000$ years. Discovered in 1931, teeth made of nacre in Mayan skulls integrated perfectly into the surrounding bone [Fig. 2(A)]. ${ }^{20}$ The suggested use of nacre as a bone graft substitute was a major breakthrough made in 1992, when Lopez et al. ${ }^{26}$ discovered that the nacre from $P$. maxima was simultaneously biocompatible and osteoinductive. Ever since, attention has been paid continuously to nacre. In what follows, results of the major in vivo and in vitro studies will be introduced.

In vivo studies. Inspired by the nacre teeth found in Mayan skulls, nacre, as a bone graft substitute, was first designed many centuries later to restore dental defects in dogs and humans. ${ }^{21,27}$ For the last 20 years, nacre has been designed more ingeniously and tested, in vivo, at various implantation sites for different uses (Table I and Fig. 2). New bone formation stimulated by nacre has been observed in humans, rats, sheep, rabbits and pigs. The implantation site involved the maxillary, mandible [Fig. 2(B)], midshaft of femur or femoral epiphysis, first metatarsus, in lumbar vertebrae or between the transverse processes. More recently, nacre has been designed as an injectable powder [Fig. 2(C)], or in the shape of rods [Fig. 2(D)], trochlea [Fig. 2(E)], screws [Fig. $2(\mathrm{~F})]$ and plates, to match the clinical needs for orthopaedic bone devices.

Biocompatibility, osteoinduction, osteoconduction, and osseointegration of nacre. In 1997, Atlan et al. $^{28}$ mixed fine nacre powder into a slurry with the blood of eight patients suffering from bone loss in their upper jaw. The slurry was injected into tissues where the bone was missing. After 6 months, biopsies showed that the nacre had been well accepted by the local tissues. The newly formed bone was tightly welded to the nacre particles without any intervention of soft or fibrous tissue [Fig. 3(A)]. Osteoblasts had been activated and new healthy bone had formed throughout the implant [Fig. 3(B)], while the nacre particles slowly dissolved away gradually and centripetally, replaced by immature woven bone and then mature lamellar bone [Fig. 3(C)]. Thus, the qualities of biocompatibility, osteoinduction, osteoconduction, and osseointegration of nacre were all proven in a human, which was further confirmed 

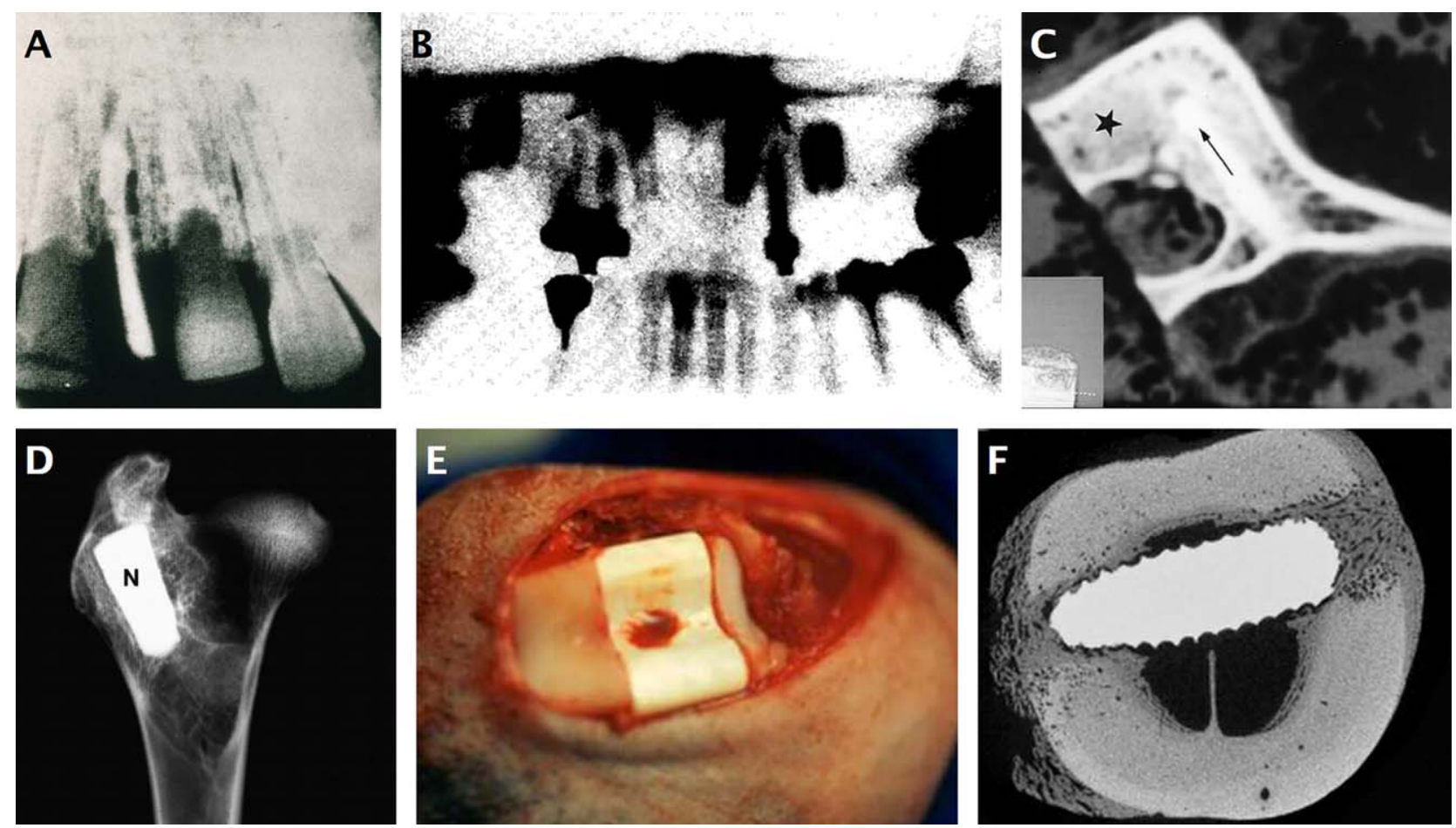

FIGURE 2. Different designs of nacre as Bone graft substitutes. A: Nacre incisor in the jaw of an Ancient Mayan individual. Excellent bone fusion was shown by X-ray imaging, ${ }^{20} \mathrm{~B}$ : bioracine of nacre at levels of $12,22,15$, and 25 in human maxillary, 4 months after implantation; ${ }^{21} \mathrm{C}$ : Injectable powder of nacre $(\star)$, implanted in sheep vertebrae, 1 week after implantation; ${ }^{22} \mathrm{D}$ : Nacre $(\mathrm{N})$ in cylinder shape implanted in sheep femoral epiphysis, 10 months after implantation; ${ }^{23} \mathrm{E}$ : Nacre in trochlea shape as substitute of sheep femoral trochlea; ${ }^{24} \mathrm{~F}$ : Nacre (N) in screw shape implanted in sheep first metatarsus, 2 months after implantation. ${ }^{25}$

by all the subsequent in vivo studies when nacre was implanted in a bone environment (Fig. 4).

Comparison between nacre and autologous bone graft. Lamghari et al. ${ }^{32}$ implanted nacre in rabbits to evaluate the possibility of arthrodesis of lumbar spine transverse processes for 11 weeks. The nacre was compared to autologous bone grafts from the iliac crest of each rabbit. Results showed that nacre was well tolerated by the host tissue, stimulated a continuing endochondral bone formation, and formed a solid fusion between the transverse processes in one-third of the rabbits by week 5 and two-thirds after 11 weeks. After that period, a solid fusion was formed in all rabbits implanted with autologous bone graft, and no bone formation in sham operated rabbits. Thus, nacre induced spinal fusion in an acceptable percentage of the cases.

Comparison between nacre and hydroxyapatite coated titania (THA). The comparison between raw nacre and THA was made after 14 days of implantation in the midshafts of rat femurs. ${ }^{29}$ By in situ hybridization using RNA probes complementary to collagen I RNA, osteonectin RNA and osteocalcin RNA, nacre cylinders stimulated a faster osteogenesis, which progressed beyond the phase of maximal synthetic activity, and a better osseointegration was observed than with THA.
Comparison between nacre and $\beta$-tricalcium phosphate ( $\beta$-TCP). Rod-shaped nacre or $\beta$-TCP were implanted in the mandible of 8 male guinea pigs by bilateral drilling procedures, while 2 pigs were sham-operated. ${ }^{34}$ The results showed that nacre induced the highest amount of new bone formation, followed by the $\beta$-TCP and the sham-operated group, respectively.

Comparison between nacre and polymethylmethacrylate (PMMA). Lamghari et al. ${ }^{2,25,31}$ compared nacre powder and PMMA in sheep vertebrae. Experimental cavities were prepared in the lumbar vertebrae of sheep, and then filled with injectable nacre powder [Figs. 2(C) and 4(D)], PMMA or left empty. The vertebrae sections were performed 1, 8, 12 weeks after surgery, and evaluated histologically and morphometrically. The empty cavities were filled by fatty diffuse tissue [Fig. 4(C)]. No new bone was formed in the empty cavities [Fig. 4(E)], nor in those filled with PMMA. However, layers of newly formed bone, both woven and lamellar, in different stages of maturation in contact with or adjacent to the dissolving nacre powder were observed [Fig. 4(F)], confirming the results of an earlier study. ${ }^{28}$

Biodegradability of nacre. To understand the mechanisms of biodegradation is an important issue in the choice of materials and implant design. ${ }^{30}$ The shape of nacre implants and endosseous sites are two important factors. 
TABLE I. In Vivo Studies on the Osteogenic Activity of Nacre as a Bone Graft Substitute

\begin{tabular}{|c|c|c|c|c|}
\hline Reference & $\begin{array}{l}\text { Species of Nacre; } \\
\text { Implant Design }\end{array}$ & $\begin{array}{l}\text { Experimental Subject; } \\
\text { Implantation } \\
\text { Site }(n=)\end{array}$ & Follow-up & Principal Results \\
\hline $1997^{28}$ & $\begin{array}{l}\text { P. maxima; powder, } \\
\text { particle size: } 50-100 \\
\mu \mathrm{m} \text {, mixed with auto- } \\
\text { logous venous blood }\end{array}$ & $\begin{array}{l}\text { Human (8), maxillary } \\
\text { alveolar bone }\end{array}$ & 6 months & $\begin{array}{l}\text { Osteogenesis, biodegradable gradu- } \\
\text { ally and centripetally, replaced } \\
\text { with immature and then mature } \\
\text { lamellar bone }\end{array}$ \\
\hline $1997^{29}$ & $\begin{array}{l}\text { P. margaritifera; } \\
\text { cylinders, } \\
\text { 2-mm diameter and } \\
\text { 3-mm high }\end{array}$ & $\begin{array}{l}\text { Rat }(-) \text {, midshaft } \\
\text { femur }\end{array}$ & 14 days & $\begin{array}{l}\text { Nacre has a higher osteogenic } \\
\text { bioactivity than titania- } \\
\text { hydroxyapatite composite }\end{array}$ \\
\hline $1999^{23}$ & $\begin{array}{l}\text { P. maxima; cylinder, } \\
\text { 6-mm mean diameter; } \\
\text { 15-mm length }\end{array}$ & $\begin{array}{l}\text { Sheep (6), femoral } \\
\text { epiphysis }\end{array}$ & $\begin{array}{l}3 \text { months }(n=3) \\
10 \text { months }(n=3)\end{array}$ & $\begin{array}{l}\text { Osteogenesis and biocompatibility } \\
\text { of nacre, continuity between the } \\
\text { nacre and the bone }\end{array}$ \\
\hline $2000^{30}$ & $\begin{array}{l}\text { P. margaritifera; } \\
\text { granules: diameters } \\
<2 \mathrm{~mm}\end{array}$ & $\begin{array}{l}\text { Rat }(72) \text {, back muscle } \\
\text { and femur }\end{array}$ & $\begin{array}{c}1,2,4,8, \text { and } 16 \\
\text { weeks }\end{array}$ & $\begin{array}{l}\text { Nacre is biocompatible, biodegrad- } \\
\text { able and osteoconductive materi- } \\
\text { als; Aragonite-bone } \\
\text { bonding via a phosphorous-rich } \\
\text { layer }\end{array}$ \\
\hline $2001^{31}$ & $\begin{array}{l}\text { P. maxima; mixture of } \\
\text { powder (particle size: } \\
50-150 \mu \mathrm{m} \text { ) with } \\
\text { autologous venous } \\
\text { blood }\end{array}$ & $\begin{array}{l}\text { Sheep (11), upper } \\
\text { lumbar vertebrae } \\
\text { (L1-L7) }\end{array}$ & $\begin{array}{l}1 \text { week }(n=3) \\
2 \text { months }(n=3) \\
3 \text { months }(n=5)\end{array}$ & $\begin{array}{l}\text { Nacre stimulates bone-forming cells } \\
\text { in vertebrae and results in new } \\
\text { bone formation }\end{array}$ \\
\hline $2001^{32}$ & $\begin{array}{l}P . \text { maxima; mixture of } \\
\text { powder (particle size: } \\
50-150 \mu \mathrm{m} \text { ) with auto- } \\
\text { logous venous blood; } \\
\text { graft volume: } 2.5 \mathrm{~mL}\end{array}$ & $\begin{array}{l}\text { Rabbit (15), lumbar } \\
\text { vertebrae (L5-L6) }\end{array}$ & $\begin{array}{l}2 \text { weeks }(n=3) \\
5 \text { weeks }(n=3) \\
11 \text { weeks }(n=3)\end{array}$ & $\begin{array}{l}\text { Nacre stimulates the formation of a } \\
\text { bone bridge between the trans- } \\
\text { verse processes of rabbit lumbar } \\
\text { vertebrae }\end{array}$ \\
\hline $2005^{33}$ & $\begin{array}{l}\text { P. maxima; nacre pieces, } \\
20 \mathrm{~mm} \text { length and } \\
13 \mathrm{~mm} \text { in diameter }\end{array}$ & $\begin{array}{l}\text { Sheep (14), midshaft } \\
\text { femur }\end{array}$ & $\begin{array}{l}3 \text { months }(n=5) \\
6 \text { months }(n=5) \\
9 \text { months }(n=4)\end{array}$ & $\begin{array}{l}\text { Raw nacre implants are sustained } \\
\text { when implanted into bone tissue } \\
\text { in spite of a limited biodegrada- } \\
\text { tion process }\end{array}$ \\
\hline $2012^{34}$ & $\begin{array}{l}P . \text { maxima; rod-shaped, } \\
2 \times 2 \times 2 \mathrm{~mm}^{3}\end{array}$ & Pig (10), mandible & $\begin{array}{l}1 \text { month }(n=5) \text {, } \\
2 \text { months }(n=5)\end{array}$ & $\begin{array}{l}\text { Nacre-implanted group exhibits the } \\
\text { highest new bone formation, } \\
\text { without any fibrous tissue, com- } \\
\text { pared to } \beta \text {-tricalcium phosphate } \\
\text { implanted or sham-operated } \\
\text { group }\end{array}$ \\
\hline $2012^{24}$ & $\begin{array}{l}\text { P. maxima; trochlea } \\
\text { shape }(22 \times 15 \times \\
\left.10 \mathrm{~mm}^{3}\right)\end{array}$ & $\begin{array}{l}\text { Sheep (6), femoral } \\
\text { trochlea }\end{array}$ & $\begin{array}{l}3 \text { months }(n=3) \\
6 \text { months }(n=3)\end{array}$ & $\begin{array}{l}\text { Biocompatibility, good tolerance in } \\
\text { joint, osteochondroinductivity, } \\
\text { endochondral ossification }\end{array}$ \\
\hline $2014^{25}$ & P. maxima; screws & $\begin{array}{l}\text { Sheep (5), first } \\
\text { metatarsus }\end{array}$ & 2 months & $\begin{array}{l}\text { Erosion of nacre is observed; The } \\
\text { interface shows a toothed-comb } \\
\text { appearance; The interposing } \\
\text { organic layer is not observed }\end{array}$ \\
\hline
\end{tabular}

When raw pieces of nacre were implanted in dogs, ${ }^{27}$ or humans' dental defects, ${ }^{21}$ or sheep femur epiphysis ${ }^{23}$ for as long as 10 months, nacre appeared sustained, and no osteoclasts or absorption was observed at the bone/nacre interface. On the other hand, nacre powder (particle size 50-150 $\mu \mathrm{m})$ was gradually dissolved in rabbit vertebrae, beginning 8 weeks after surgery. ${ }^{28}$ No giant cells or macrophages were observed. ${ }^{36}$ The result was confirmed by the study in a human maxillary, ${ }^{28}$ over 6 months after implantation, and 16 weeks after implantation in rat femurs. ${ }^{30}$ It was believed that a physicochemical dissolution was involved in the biodegradation of nacre, ${ }^{30}$ but, some nacre powder was always observed at the end of all these studies.
Later, it was revealed that the change rate of the nacre/ bone surface depended on the endosseous implantation site and the nacre/bone interaction. ${ }^{33}$ Smooth-surfaced nacre pieces were implanted in sheep femurs after a midshaft hemidiaphysis resection of the femur bone to match the nacre. Bone/nacre and bone-marrow/nacre interfaces were analyzed at 3, 6, and 9 months after the surgery. The results showed that, the nacre surfaces facing bone marrow were always more irregular than when implanted in a mineralized-bone, and the changes at the nacre interfaces appeared to be site-dependent rather than time related. The presence of giant macrophage cells was confirmed in the first metatarsus of sheep, submitted to a simultaneous 

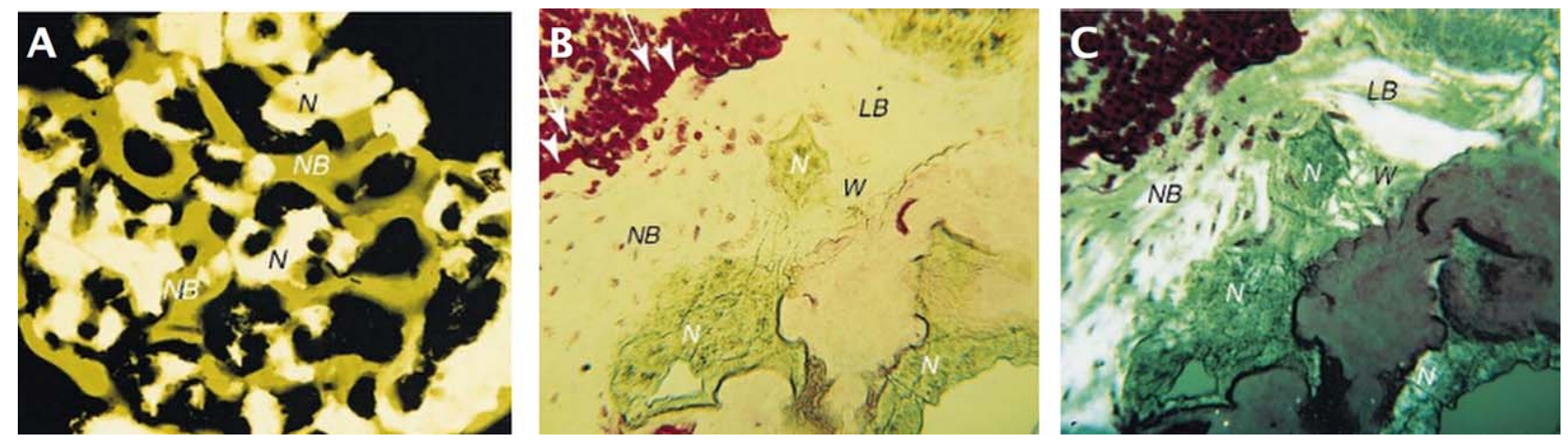

FIGURE 3. Osseointegration of nacre in human bone environment. Nacre powder was implanted in defective human maxillary bone; the images here were taken after 6 months of implantation. ${ }^{28,35}$ The images above are respectively microradiography (A), histological (B, basic fuchsine staining) and polarised light images (C). A shows newly-formed bone ( $N B$, low X-ray density) throughout the nacre ( $N$, high $\mathrm{X}$-ray density), welded together without intervening fibrous tissue, as shown in $B$. The bone surface was covered by the osteoid borders lined with osteoblasts. C: The new bone was composed of woven bone $(W)$ and lamellar bone $(L B)$ in close contact with the nacre implants. $A \times 26$; $B$ and $C, \times 157$.

remodelling process that implied both erosion by giant macrophage cells, and bone apposition on the previously eroded areas [Fig. $4(\mathrm{~A}, \mathrm{~B})] .^{25}$ In general, the in vivo biodegradability of nacre is a highly variable parameter depending on the size, shape, and endosseous implantation site. Nacre blocks are sustained during a period of bone regeneration and bone remodelling though a limited biodegradation, while, nacre powder dissolves much more quickly than nacre blocks. It is possible to make nacre absolutely degradable for a short period if the nacre powder is fine enough.

\section{In vitro studies}

In vitro studies, of which the results are shown in Table II, have been carried out to explain all that has been observed in
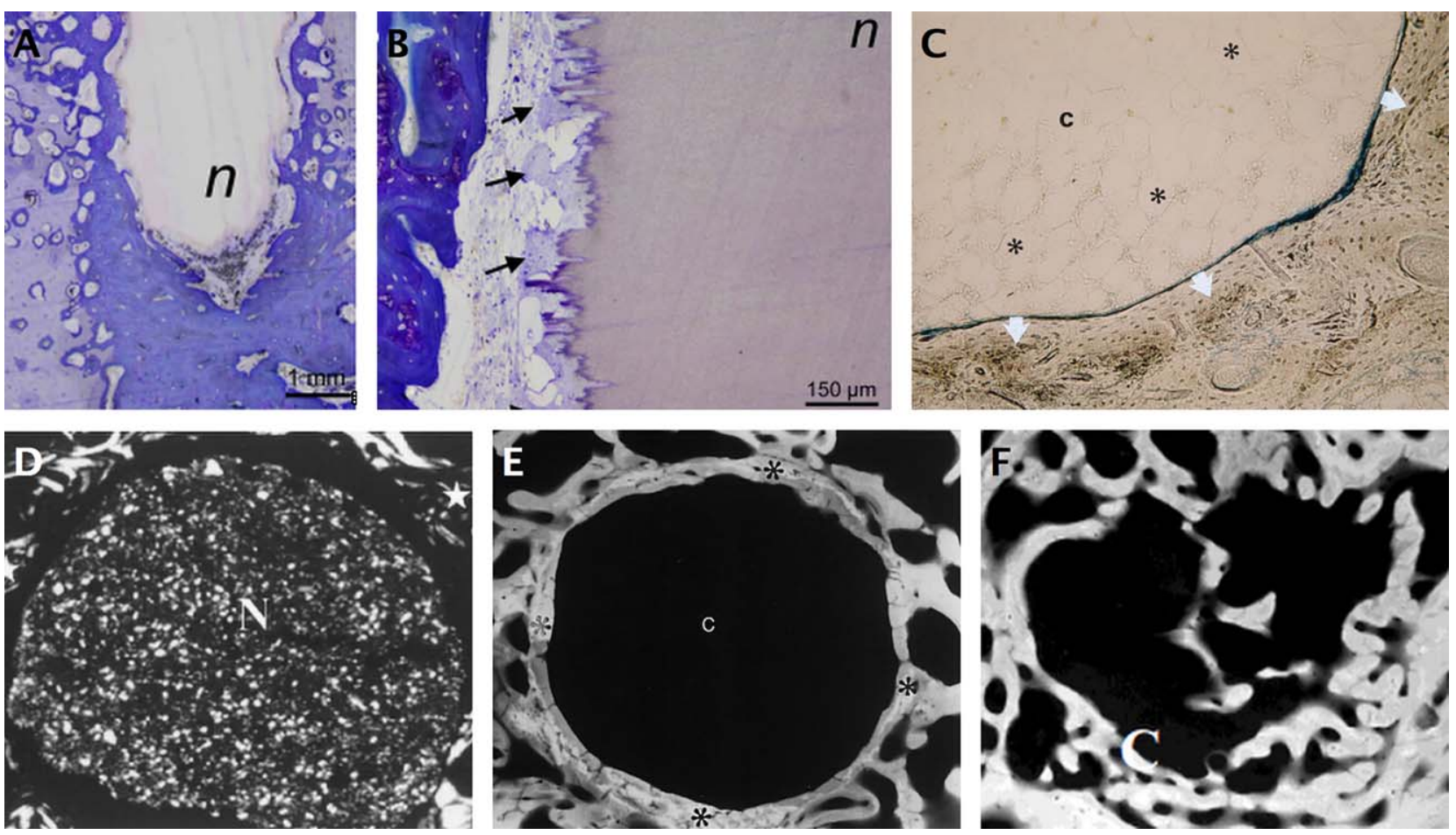

FIGURE 4. Osseointegration and biodegradation of nacre in sheep. A: Histological aspect of nacre screw after a 2-month implantation period in the first metatarsus. ${ }^{25}$ Note the nacre erosion by giant cells; $B$ is a higher magnification of $A$ at the interface, showing bone apposition and erosion of nacre. Toluidine blue staining: Bone (in blue) and nacre ( $n$, unstained); C: Histology of empty cavity (light microscopy) in vertebrae, showed a bone defect at 12 weeks post-surgery. Cavity (C) was filled by fatty diffuse tissue $\left({ }^{*}\right)$. Body of the vertebrae (white arrow), $\times 40 ;{ }^{25} \mathrm{D}$ to $\mathrm{F}$ show bone defects in vertebrae. ${ }^{22} \mathrm{D}$ : Bone cavity was filled with nacre powder $(\mathrm{N})$, 1 week post-surgery; vertebral trabecular bone $(\star)$, polarised light image, $\times 25$; E: The bone around the cavity $(\mathrm{C})$ without nacre was organised into concentric rings $(*)$, no new bone formation at 12 weeks post-surgery, contact microradiograph, $\times 25$; F: New bone formation and bone remodelling were observed in the cavity (C) with nacre at 8 weeks post-surgery, contact microradiograph, $\times 25$. 
TABLE II. In Vitro Studies on Nacre's Osteogenic Activity

\begin{tabular}{|c|c|c|}
\hline Reference & $\begin{array}{l}\text { Nacre Species and Treatment; } \\
\text { Cells and Culture Time }\end{array}$ & Principal Results \\
\hline $1992^{26}$ & $\begin{array}{l}\text { P. maxima; Nacre chips }\left(500-750 \mu \mathrm{m}^{*} 100 \mu \mathrm{m}\right) \\
\text { Human alveolar maxillary osteoblasts; } 5-7 \\
\text { weeks }\end{array}$ & $\begin{array}{l}\text { General chemical inducers not required to obtain bone } \\
\text { formation; Human osteoblasts proliferated and were } \\
\text { clearly attracted by nacre chips; Bone formation in the } \\
\text { presence of nacre }\end{array}$ \\
\hline $1992^{37}$ & $\begin{array}{l}\text { P. maxima; Nacre chips }\left(1 \mathrm{~mm}^{3}\right) \text {; } \\
\text { Human alveolar maxillary osteoblasts; } \\
4-6 \text { weeks }\end{array}$ & $\begin{array}{l}\text { Nacre induces different types of mineralisation in } \\
\text { human osteoblasts }\end{array}$ \\
\hline $1999^{36}$ & P. maxima; $\mathrm{WSM}^{\mathrm{a}} ; \mathrm{rBMSC}^{\mathrm{b}} ; 7$ days & $\begin{array}{l}\text { WSM activates osteogenic bone marrow cells with } \\
\text { enhanced alkaline phosphatase activity }\end{array}$ \\
\hline $2001^{38}$ & P. maxima; WSM; MRC-5 ${ }^{\mathrm{c}}, \mathrm{rBMSC} ; 13$ days & $\begin{array}{l}\text { In rBMSC, WSM promotes the cell proliferation and } \\
\text { ALP }^{\mathrm{g}} \text { activity as dexamethasone }\end{array}$ \\
\hline $2001^{39}$ & $\begin{array}{l}\text { P. maxima; WSM and HPLC fraction; rat parie- } \\
\text { tal osteoblasts; } 9 \text { days }\end{array}$ & $\begin{array}{l}\text { Nacre extract and the HPLC fraction have no effect on } \\
\text { the proliferation of mature osteoblasts; Nacre extract } \\
\text { stimulates Bcl-2 production in osteoblast }\end{array}$ \\
\hline $2002^{40}$ & $\begin{array}{l}\text { P. maxima; WSM and four HPLC fractions; } \\
\text { MRC-5, rBMSC, rat calvaria osteoblasts; } 13 \\
\text { days }\end{array}$ & $\begin{array}{l}\text { WSM contains signal molecules that can stimulate the } \\
\text { osteogenic pathway in mammalian cells }\end{array}$ \\
\hline $2003^{17}$ & P. maxima; WSM; MC3T3-E1 ${ }^{\mathrm{d}} ; 6$ days & $\begin{array}{l}\text { WSM speeds up the differentiation and mineralisation } \\
\text { more effectively than dexamethasone; WSM inhibits } \\
\text { ALP activity and that of dexamethasone }\end{array}$ \\
\hline $2003^{41}$ & $\begin{array}{l}\text { P. maxima; WSM; MRC-5, rBMSC, MC3T3-E1, } \\
\text { MG63; } 14 \text { days }\end{array}$ & $\begin{array}{l}\text { WSM contains the signals responsible for the biological } \\
\text { activity of the whole nacre; WSM acts in particular on } \\
\text { osteoblastic cell differentiation up until mineralisation }\end{array}$ \\
\hline $2004^{42}$ & $\begin{array}{l}\text { Haliotis tuberculata; WSM; MRC-5, rBMSC, } \\
\text { MC3T3-E1, MG63; } 14 \text { days }\end{array}$ & $\begin{array}{l}\text { WSM contains signal molecules responsible for the } \\
\text { recruitment of mammal cells in the osteogenic path- } \\
\text { way and bone cell activation undergoing a complete } \\
\text { sequence of mineralisation }\end{array}$ \\
\hline $2006^{43}$ & $\begin{array}{l}\text { P. fucata; Matrix protein } \mathrm{p} 10 \text { from nacre; } \\
\text { MRC-5, MC3T3-E1; } 7 \text { days }\end{array}$ & $\begin{array}{l}\text { p10 increases ALP activity, while the viability of MRC-5 } \\
\text { and MC3T3-E1 remained unchanged after treatment } \\
\text { of } p 10\end{array}$ \\
\hline $2007^{44}$ & $\begin{array}{l}\text { P. margaritifera; Slices of cylinder, } 6 \mathrm{~mm} \\
\text { in diameter, } 800 \mu \mathrm{m} \text { slices; Human } \\
\text { osteoclast precursors, mouse osteoclast } \\
\text { precursors, rabbit mature osteoclasts; } 24 \mathrm{~h}\end{array}$ & Osteoclastic degradation of nacre is a limited process \\
\hline $2007^{45}$ & $\begin{array}{l}P . \text { fucata; Protein complex p60 from nacre } \\
\text { (decalcification process); MC3T3-E1, rBMSC; } \\
8 \text { days }\end{array}$ & $\begin{array}{l}\text { Von Kossa staining shows the formation of mineralised } \\
\text { nodules in the two cell types after the treatment of } \\
\text { p60 without ascorbic acid and } \beta \text {-glycerophosphate }\end{array}$ \\
\hline $2008^{46}$ & $\begin{array}{l}\text { Nacre species unknown; WSM; Rabbit bone } \\
\text { marrow stromal cells; } 7 \text { days }\end{array}$ & $\begin{array}{l}\text { WSM increases ALP activity, and the expression of } \\
\text { BMP-2, but not Runx2 }\end{array}$ \\
\hline $2007^{47}$ & $\begin{array}{l}\text { P. maxima; Low molecular weight molecules } \\
(50-235 \mathrm{Da}) \text { of WSM; MC3T3-E1; } 25 \text { days }\end{array}$ & $\begin{array}{l}\text { WSM speeds up the differentiation and mineralisation } \\
\text { of damaged bone tissue; Hydroxyapatite was found in } \\
\text { cells treated with WSM }\end{array}$ \\
\hline $2012^{48}$ & $\begin{array}{l}\text { Pteria martensii; WSM and nacre powder; } \\
\text { Mouse calvaria osteoblast precursors, bone } \\
\text { marrow derived osteoclast precursors; } 10 \\
\text { and } 2 \text { days, respectively }\end{array}$ & $\begin{array}{l}\text { WSM induces osteoblast biomineralisation compared to } \\
\text { calcium dissolved from } \mathrm{CaCO}_{3} \text {. WSM suppresses } \\
\text { osteoclast formation; Related signaling pathways are } \\
\text { also revealed }\end{array}$ \\
\hline $2013^{49}$ & P. fucata; WSM; MC3T3-E1; 9 days & $\begin{array}{l}\text { WSM induces differentiation of the preosteoblasts in } \\
\text { mature osteoblasts }\end{array}$ \\
\hline $2015^{50}$ & $\begin{array}{l}\text { P. maxima; WSM and nacre chips }(500-750 \mu \mathrm{m} \\
\times 100 \mu \mathrm{m}) ; \text { Human bone marrow stromal } \\
\text { cells; } 21 \text { days }\end{array}$ & $\begin{array}{l}\text { Nacre induces the early stages of human bone cell } \\
\text { differentiation }\end{array}$ \\
\hline $2015^{51,52}$ & $\begin{array}{l}\text { P. margaritifera; } \mathrm{ESM}^{\mathrm{f}} \text {; MC3T3-E1 and human } \\
\text { osteoblasts; } 21 \text { days }\end{array}$ & $\begin{array}{l}\text { ESM can restore the mineralisation capacity of osteoar- } \\
\text { thritis osteoblasts }\end{array}$ \\
\hline
\end{tabular}

aWSM: water soluble matrix.

${ }^{b}$ rBMSC: rat bone marrow stromal cells.

${ }^{\mathrm{c}} \mathrm{MRC}-5$ : human fetal lung tissue fibroblasts cell line.

${ }^{\mathrm{d} M C 3 T 3-E 1:}$ murine calvaria pre-osteoblasts cell line.

eMG63: human osteosarcoma cell line.

fESM: ethanol soluble matrix.

${ }^{\mathrm{g}} \mathrm{ALP}$ : alkaline phosphatase. 
in vivo studies. As nacre is osteoinductive in vivo and manifests many great qualities as a bone graft substitute, it is important to determine the internal mechanisms of action and to identify the responsible signal molecules in the osteogenic process, before the routine use of nacre in clinics.

Biocompatibility, osteoinduction, osteoconduction of nacre, and the mechanisms of its action. When nacre chips were placed with human alveolar maxillary osteoblasts, without any regular chemical inducers to obtain bone mineralization in vitro, osteoblasts proliferated and were attracted by nacre chips. The osteoblasts surrounding the nacre chips mineralised preferentially, suggesting that nacre was biocompatible, osteoinductive and osteoconductive. $^{26}$ As a pioneering model, the studies were repeated, ${ }^{37,39,40}$ and developed in order to explore the mechanisms of osteoinduction by nacre. Then the nacre chips were placed beside bone chips on a layer of human osteoblasts: a strong osteogenic effect of the nacre on the osteoblasts was observed. New bone formation occurred by growth on the existing bone and by the formation of mineralised nodules within the matrix adjacent to the bone explant. ${ }^{37}$ This phenomenon confirmed the results observed in a study in vivo. ${ }^{28}$ It's believed that nacre contains some signal molecules that are released when placed in living systems. Nacre could attract and activate both bone marrow stem cells and osteoblasts. ${ }^{35}$ Related to nacre extracts, water soluble matrix (WSM), or a fraction thereof, was mostly tested. WSM can be extracted by water without decalcification. It was argued that osteoblastic cells from marrow or other bone surface-derived osteoblast stem cells had the inherent direct potential for osteogenesis. ${ }^{38}$ Thus, rat bone marrow stomal cells (rBMSCs), ${ }^{36,38,40,41}$ human fibroblast cell lines from fetal lung tissue (MRC-5), ${ }^{38,40,41}$ a model of immature osteoblasts, human osteosarcoma cell lines (MG63), ${ }^{41,42}$ and human bone marrow stomal cells (hBMSCs), ${ }^{50}$ were used for evaluating the osteostimulatory effect of WSM in the early stages of cellular differentiation. The MC3T3-E1 pre-osteoblast cell line from mouse calvaria has also been widely used $17,41,42,47,49$ : it can differentiate into osteoblasts and mineralize in the presence of $\beta$ glycerophosphate and ascorbic acid. WSM extensively enhanced the alkaline phosphatase (ALP) activity, an early marker of cellular osteogenic differentiation, in all cells tested, ${ }^{36,38-40,42,46,49,50}$ but only in one study for MC3T3E1. ${ }^{17}$ Nacre also increased the osteocalcin levels in rBMSCs, ${ }^{41}$ and Bcl-2 production in mature rat osteoblasts. ${ }^{39}$ For the bone differentiation markers, WSM accelerated or increased the expression of Collagen I, Osteocalcin, Runx2, Osteopontin genes in MC3T3-E1, ${ }^{46,47} A L P$ in hBMSC, ${ }^{50}$ and BMP-2 but not Runx2 in rabbit BMSCs. ${ }^{46}$ WSM accelerated the hydroxyapatite deposition in MC3T3-E1, supported by Von Kossa and Alizarin Red stainings, ${ }^{17,41,46,47}$ confirmed by SEM observation and Raman spectroscopy. ${ }^{47}$ Lately, it was proven that ESM (Ethanol soluble matrix) had a similarly osteoinductive effect in MC3T3-E1 and human osteoarthritis osteoblasts. $^{51,52}$
Identification of active nacre compounds for osteogenesis. HPLC fractions of WSM, for example, p10 and p60, were demonstrated to have an osteostimulatory effect. $^{38,39,45,49}$ The nacre proteins were equally proven to play a primary role in controlling the formation of the interfacial structure and biocompatibility with bone as well as the stability of biogenic tissues. ${ }^{53}$ It has been argued that the nacre molecules efficient in bone cell differentiation are probably more related to peptides. ${ }^{17,47}$ Much effort is presently being made to discover the active compounds responsible for the osteogenic property of nacre.

Biodegradability of nacre. When human osteoclast precursors from blood, mouse osteoclast precursors from spleen and mature rabbit osteoclasts from long bones were cultured with nacre slices, osteoclast precursors differentiated into osteoclasts capable of resorbing nacre. But nacre resorption efficiency was always lower than that of bone and appeared to be a limited process. ${ }^{44}$ Even more, WSM suppresses the osteoclast formation. ${ }^{48}$ Thus, the cellmediated absorption of nacre slices in vitro was limited.

\section{DISCUSSION AND CONCLUSION}

What might reasonably be seen as nacre's contribution to current orthopaedic clinics?

Having witnessed the various designs of nacre in in vivo studies, it is easy to envisage some specific uses of nacre in orthopaedic clinics. As blocks, pieces, chips or in the shape of bone devices, nacre can be used (i) to offer mechanical support at load-bearing sites, for example, at defects in major long bones and in the jaw bone and (ii) to fill large bone defects at no-load sites, for example, the cranial defect. Nacre can also be used to promote an intervertebral or interlaminar fusion when an open dissection is taken. Finally, nacre offers a permanent fixation between fractured bones and there is no need to remove it after an implant. Nacre's biocompatibility, osteoinductivity, osteoconductivity and its excellent mechanical properties all benefit from its large-scale availability. As no a powder, nacre can be used as an injectable material to fit certain mini-invasive surgery needs, particularly in spinal surgery. The injectable material may also have a better market for filling semi-closed bone defects caused by cyst or benign tumours than nacre pieces. Being added into other grafting biomaterials, nacre may improve the osteoinductivity and osteoconductivity. In addition, nacre powder may be used as a basal and machinable biomaterial in 3D printing, to make a personalized implant for nonload bearing bone defects. ${ }^{54}$ Nacre extracts could be used as surface-coatings for different bone graft substitutes to improve the osteoinductivity, ${ }^{55}$ by stimulating osteoblasts and suppressing osteoclasts. To date, it seems that no material is perfect for bone repair. The current strategies for bone graft substitutes are confronted with incredible complexity and difficulty, many of which could be avoided, by using nacre, an outstanding biomaterial. This natural marine biomaterial possesses many advantages, for example, low cost, sophisticated predesign of hierarchical structures and architectures for bio recognition, intrinsic biological 
functions, possibility of low-level immunogenicity, low cytotoxicity, and easy safe storage. ${ }^{56}$ Because of its remarkable mechanical properties and biological effects in the bone environment, nacre can be designed specifically to correspond to each of the multiple clinical needs for bone graft substitution or bone regeneration. Though further progress in our understanding must still be made, we fully believe that nacre has a revolutionary potential in the field of bone substitutes.

\section{ACKNOWLEDGMENTS}

The authors are grateful to Dr. E. McRae for carefully reading over the manuscript.

\section{REFERENCES}

1. Graham SM, Leonidou A, Aslam-Pervez N, Hamza A, Panteliadis $P$, Heliotis M, Mantalaris A, Tsiridis E. Biological therapy of bone defects: The immunology of bone allo-transplantation. Expert Opin Biol Ther 2010;10:885-901.

2. Laurencin C, Khan Y, El-Amin SF. Bone graft substitutes. Expert Rev Med Dev 2006;3:49-57.

3. Hollister SJ, Murphy WL. Scaffold translation: Barriers between concept and clinic. Tissue Eng Part B Rev 2011;17:459-474.

4. Brydone AS, Meek D, Maclaine S. Bone grafting, orthopaedic biomaterials, and the clinical need for bone engineering. Proc Inst Mech Eng 2010;224:1329-1343.

5. Albrektsson T, Johansson C. Osteoinduction, osteoconduction and osseointegration. Eur Spine J 2001;10:S96-101.

6. Yuan H, De Bruijn JD, Zhang X, Van Blitterswijk CA, De Groot K. Use of an osteoinductive biomaterial as a bone morphogenetic protein carrier. J Mater Sci Mater Med 2001;12:761-766.

7. Amini AR, Laurencin CT, Nukavarapu SP. Bone tissue engineering: Recent advances and challenges. Crit Rev Biomed Eng 2012 ; 40:363-408

8. O'Keefe RJ, Mao J. Bone tissue engineering and regeneration: From discovery to the clinic-An overview. Tissue Eng B Rev 2011;17:389-392.

9. Lafage-Proust M-H, Prisby $\mathrm{R}$, Roche B, Vico L. Bone vascularization and remodeling. Joint Bone Spine 2010;77:521-524.

10. Bellaaj-Zouari A, Dkhili S, Gharsalli R, Derbali A, Aloui-Bejaoui N. Shell morphology and relative growth variability of the invasive pearl oyster Pinctada radiata in coastal Tunisia. J Mar Biol Assoc UK 2012;92:553-563.

11. Nudelman F, Shimoni E, Klein E, Rousseau M, Bourrat $X$, Lopez E, Addadi L, Weiner S. Forming nacreous layer of the shells of the bivalves Atrina rigida and Pinctada margaritifera: An environmental- and cryo-scanning electron microscopy study. J Struct Biol 2008;162:290-300.

12. Watabe N. Studies on shell formation: XI. Crystal-Matrix relationships in the inner layers of mollusk shells. J Ultrastruct Res 1965;12:351-370.

13. Rousseau M, Lopez E, Stempflé P, Brendlé M, Franke L, Guette A, Naslain R, Bourrat X. Multiscale structure of sheet nacre. Biomaterials $2005 ; 26: 6254-6262$.

14. Currey JD, Zioupos P, Peter D, Casinos A. Mechanical properties of nacre and highly mineralized bone. Proc R Soc B Biol Sci 2001; 268:107-111.

15. Song F, Soh AK, Bai YL. Structural and mechanical properties of the organic matrix layers of nacre. Biomaterials 2003;24:36233631.

16. Marin F, Le Roy N, Marie B. The formation and mineralization of mollusk shell. Front Biosci 2012;4:1099-1125.

17. Rousseau M. The water-soluble matrix fraction from the nacre of Pinctada maxima produces earlier mineralization of MC3T3-E1 mouse pre-osteoblasts. Comp Biochem Physiol B Biochem Mol Biol 2003;135:1-7.

18. Kronenberg HM. Developmental regulation of the growth plate. Nature 2003;423:332-336.
19. Zioupos $P$, Currey JD, Hamer AJ. The role of collagen in the declining mechanical properties of aging human cortical bone. J Biomed Mater Res 1999;45:108-116.

20. Bobbio A. The first endosseous alloplastic implant in the history of man. Bull Hist Dent 1972;20:1-6.

21. Camprasse S, Camprasse G, Pouzol M, Lopez E. Artificial dental root made of natural calcium carbonate (Bioracine). Clin Mater 1990:5:235-250.

22. Lamghari M, Huet $H$, Laurent A, Berland S, Lopez E. A model for evaluating injectable bone replacements in the vertebrae of sheep: Radiological and histological study. Biomaterials 1999;20: 2107-2114.

23. Atlan G, Delattre O, Berland S, LeFaou A, Nabias G, Cot D, Lopez E. Interface between bone and nacre implants in sheep. Biomaterials 1999;20:1017-1022.

24. Rousseau M, Delattre O, Gillet $P$, Lopez E. Subchondral nacre implant in the articular zone of the sheep's knee: A pilot study. Biomed Mater Eng 2012;22:227-234.

25. Pascaretti-Grizon F, Libouban H, Camprasse G, Camprasse S, Mallet R, Chappard D. The interface between nacre and bone after implantation in the sheep: A nanotomographic and Raman study: Bone-nacre interface. J Raman Spectrosc 2014;45:558-564.

26. Lopez E, Vidal B, Berland S, Camprasse S, Camprasse G, Silve C. Demonstration of the capacity of nacre to induce bone formation by human osteoblasts maintained in vitro. Tissue Cell 1992;24: 667-679.

27. Camprasse G, Camprasse S, Gill GA. Substitution of the dental root by aquatic invertebrate skeletons in animals and man. C R Acad Sci III Sci Vie 1988;307:485-491.

28. Atlan G, Balmain N, Berland S, Vidal B, Lopez E. Reconstruction of human maxillary defects with nacre powder: Histological evidence for bone regeneration. C R Acad Sci III Sci Vie 1997;320: 253-258.

29. Liao H, Brandsten C, Lundmark C, Wurtz T, Li J. Responses of bone to titania-hydroxyapatite composite and nacreous implants: A preliminary comparison by in situ hybridization. $J$ Mater Sci Mater Med 1997;8:823-827.

30. Liao H, Mutvei H, Sjöström M, Hammarström L, Li J. Tissue responses to natural aragonite (Margaritifera shell) implants in vivo. Biomaterials 2000;21:457-468.

31. Lamghari M, Berland S, Laurent A, Huet $H$, Lopez E. Bone reactions to nacre injected percutaneously into the vertebrae of sheep. Biomaterials 2001;22:555-562.

32. Lamghari M, Antonietti $P$, Berland S, Laurent A, Lopez E. Arthrodesis of lumbar spine transverse processes using nacre in rabbit. J Bone Miner Res 2001;16:2232-2237.

33. Berland S, Delattre O, Borzeix S, Catonné Y, Lopez E. Nacre/bone interface changes in durable nacre endosseous implants in sheep. Biomaterials 2005:26:2767-2773.

34. Asvanund $P$, Chunhabundit $P$. Alveolar bone regeneration by implantation of nacre and B-tricalcium phosphate in guinea pig. Implant Dent 2012;21:248-253.

35. Westbroek $P$, Marin F. A marriage of bone and nacre. Nature 1998;392:861-862.

36. Lamghari $M$, Almeida $M J$, Berland $S$, Huet $H$, Laurent $A$, Milet C, Lopez E. Stimulation of bone marrow cells and bone formation by nacre: in vivo and in vitro studies. Bone 1999;25:91S94S.

37. Silve C, Lopez E, Vidal B, Smith DC, Camprasse S, Camprasse G, Couly G. Nacre initiates biomineralization by human osteoblasts maintained in vitro. Calcif Tissue Int 1992;51:363-369.

38. Almeida MJ, Pereira L, Milet C, Haigle J, Barbosa M, Lopez E. Comparative effects of nacre water-soluble matrix and dexamethasone on the alkaline phosphatase activity of MRC- 5 fibroblasts. J Biomed Mater Res 2001;57:306-312.

39. Moutahir-Belqasmi F, Balmain N, Lieberrher M, Borzeix S, Berland S, Barthelemy M, Peduzzi J, Milet C, Lopez E. Effect of water soluble extract of nacre (Pinctada maxima) on alkaline phosphatase activity and $\mathrm{Bcl}-2$ expression in primary cultured osteoblasts from neonatal rat calvaria. J Mater Sci Mater Med 2001;12:1-6.

40. Mouriès LP, Almeida M-J, Milet C, Berland S, Lopez E. Bioactivity of nacre water-soluble organic matrix from the bivalve mollusk Pinctada maxima in three mammalian cell types: Fibroblasts, 
bone marrow stromal cells and osteoblasts. Comp Biochem Physiol B Biochem Mol Biol 2002;132:217-229.

41. Lopez E, Milet C, Lamghari M, Pereira Mouries L, Borzeix S, Berland S. The Dualism of Nacre. Key Eng Mater 2003;254-256: 733-736.

42. Milet $C$, Berland $S$, Lamghari M, Mouries L, Jolly $C$, Borzeix $S$, Doumenc D, Lopez É. Conservation of signal molecules involved in biomineralisation control in calcifying matrices of bone and shell. Comptes Rendus Palevol 2004;3:493-501.

43. Zhang $\mathrm{C}$, Li S, Ma Z, Xie L, Zhang R. A novel matrix Protein $\mathrm{p} 10$ from the Nacre of Pearl Oyster (Pinctada fucata) and its effects on both $\mathrm{CaCO}_{3}$ crystal formation and mineralogenic cells. Mar Biotechnol 2006;8:624-633.

44. Duplat D, Chabadel A, Gallet M, Berland S, Bédouet L, Rousseau M, Kamel S, Milet C, Jurdic P, Brazier M, Lopez E. The in vitro osteoclastic degradation of nacre. Biomaterials 2007;28:21552162.

45. Lao Y, Zhang X, Zhou J, Su W, Chen R, Wang Y, Zhou W, Xu Z-F. Characterization and in vitro mineralization function of a soluble protein complex P60 from the nacre of Pinctada fucata. Comp Biochem Physiol B Biochem Mol Biol 2007;148:201-208.

46. Wang J, Chen J, Yang C. Effects of soluble matrix of nacre on bone morphogenetic protein-2 and Cbfa1 gene expressions in rabbit marrow mesenchymal stem cells. Nan Fang Yi Ke Da Xue Xue Bao 2007;27:1838-1840.

47. Rousseau M, Boulzaguet $H$, Biagianti J, Duplat D, Milet C, Lopez $\mathrm{E}$, Bédouet $\mathrm{L}$. Low molecular weight molecules of oyster nacre induce mineralization of the MC3T3-E1 cells. J Biomed Mater Res A 2008:85A:487-497.
48. Kim H, Lee K, Ko C-Y, Kim H-S, Shin H-I, Kim T, Lee SH, Jeong D. The role of nacreous factors in preventing osteoporotic bone loss through both osteoblast activation and osteoclast inactivation. Biomaterials 2012;33:7489-7496.

49. Chaturvedi R, Singha PK, Dey S. Water soluble bioactives of nacre mediate antioxidant activity and osteoblast differentiation. PLoS One 2013;8:e84584.

50. Green DW, Kwon H-J, Jung H-S. Osteogenic potency of nacre on human mesenchymal stem cells. Mol Cells 2015;38:267-272.

51. Zhang G, Willemin AS, Brion A, Piet MH, Moby V, Bianchi $A$, Mainard D, Galois L, Gillet P, Rousseau M. A new method for the separation and purification of the osteogenic compounds of nacre ethanol soluble matrix. J Struct Biol 2016. [Epub ahead of print].

52. Brion A, Zhang G, Dossot M, Moby V, Dumas D, Hupont S, Piet $\mathrm{MH}$, Bianchi A, Mainard D, Galois L, Gillet P, Rousseau M. Nacre extract restores the mineralization capacity of subchondral osteoarthritis osteoblasts. J Struct Biol 2015;192:500-509.

53. Kim Y-W, Kim J-J, Kim YH, Rho J-Y. Effects of organic matrix proteins on the interfacial structure at the bone-biocompatible nacre interface in vitro. Biomaterials 2002;23:2089-2096.

54. Silva DN, Gerhardt de Oliveira M, Meurer E, Meurer MI, Lopes da Silva JV, Santa-Bárbara A. Dimensional error in selective laser sintering and 3D-printing of models for craniomaxillary anatomy reconstruction. J Cranio-Maxillofac Surg 2008;36:443-449.

55. Curran D, Maravic M, Kiefer P, Tochon V, Fardellone P. Epidemiology of osteoporosis-related fractures in France: A literature review. Joint Bone Spine 2010;77:546-551.

56. Green D, Lai W-F, Jung H-S. Evolving marine biomimetics for regenerative dentistry. Drugs 2014;12:2877-2912. 